\title{
35 ГОДИНИ КАТЕДРА „СОЦИАЛНА МЕДИЦИНА И ЗДРАВЕН МЕНИДЖМЪНТ“, МЕДИЦИНСКИ ФАКУЛТЕТ, ТРАКИЙСКИ УНИВЕРСИТЕТ - СТАРА ЗАГОРА
}

\section{Ю. Маринова}

$\Pi$ рез 1983 г. в състава на новооткрития Висш медицински институт в гр. Стара Загора е разкрита катедра „Социална медицина“. Неин основател и първи ръководител е доц. д-р Павел Дамянов Кушев, дм. Той ръководи катедрата от 1983 до 1987 г. Присъдено му е академично звание професор през 1984 г. Проф. Кушев е зам.-ректор по научната дейност на ВМИ от основаването му.

Катедрата се развива през годините, като наименованието ѝ търпи промени в съответствие с нормативните документи относно развитието на социомедицинския научен комплекс от дисциплини и акцентите в тяхното преподаване в университетското висше медицинско образование. Нейното наименование първоначално е „Социална хигиена и история на медицината”, след това „Социална медицина и организация на здравеопазването”, последвано от „Социална медицина и обществено здраве”, „Социална медицина и медицинска етика” и към настоящия момент „Социална медицина и здравен мениджмънт”. Съответно изискванията на Закона за висше образование, който търпи промени през годините за известен период катедрата се обособява като секция, част от по-голяма катедра с ръководител доц. д-р Живко Тодоров Караколев, дм. Катедрата отново функционира като самостоятелна структурна единица на МФ от 2004 г.

Ръководители на катедрата последователно са:

- проф. д-р Павел Дамянов Кушев, дм (1983-1987 г.). През 1984 г. му е присъдено академично звание професор. Проф. Кушев е зам.-ректор по научната дейност на ВМИ от основаването му до 1987 г.;

- доц. д-р Станка Маркова Станчева, дм (1988-1996 г.). През 1996 г. е избрана за професор по социална медицина и продължава своята професионална кариера в МУ София.;

г.).;

- доц. д-р Мария Стойкова Тодорова, дмн (2000-2001

- доц. д-р Коста Славов Костов, дм (2002-2003 г.) От 2014 г. е професор по социална медицина и понастоящем директор на Филиал Хасково, Тракийски университет Стара Загора;

- доц. д-р Юлияна Крумова Маринова, дм - от 2004 г. до момента. От 2014 г. е професор по социална медицина.

Първи асистент в катедрата е д-р Божидара Вълчева Христозова (1983-1987 г.). Асистенти в катедрата от началото на нейното основаване са също Ташо Ташев, дм и д-р Юлияна Крумова Маринова. През 1987 г. за асистенти са избрани Катя Генова Пеева и д-р Светлана Методиева Димитрова. Към този период принос за развитието на катедрата има и доц. д-р Иван Георгиев Бангьозов, дм. Асистенти в катедрата са също д-р Борислав Димитров Димитров, д-р Габриела Йорданова Велева, д-р Даниела Михайлова Колева. За периода от 2004 г. до настоящия момент за асистенти в катедрата са избрани д-р Боряна Миткова Парашкевова, д-р Галя Димитрова Чамова, Галина Илиева Петрова, Дамян Петров Петров, д-р Петър Атанасов Атанасов.

Учебната дейност в катедрата се развива от самото начало с обучение на студенти по медицина по социална медицина, медицинска статистика, медицинска социология и история на медицината във втори и пети курс. Лекционните курсове се провеждат от проф. Кушев, дм, а практическите занятия от асистентите д-р Христозова, Т. Ташев и д-р Маринова. Поставят се изключително стабилни основи и традиции за устойчивото развитие на учебно-преподавателската дейност в катедрата. За този процес и високото качество на неговото осъществяване се изграждат стабилни мостове на сътрудничество с останалите в страната висши медицински училища и научноизследователски институции. Подкрепа на преподаването по медицинска статистика се дава от проф. Димитьр Сепетлиев и от доц. Самуел Данон, които провеждат ключови лекции със студентите. Проф. д-р Миладин Апостолов дава своя принос за издигането нивото на преподаване по история на медицината. От 1986 г. се въвежда нова дисциплина за обучение „Въведение в компютърната техника“.

В периода на преход след 1989 г. предизвикателствата за преподавателския екип на катедрата са значителни. Под ръководството на проф. д-р Ст. Маркова се осъществяват съществени промени в учебната дейност на катедрата както по отношение на обема, съдържанието на преподаването, така и по отношение на самите учебни дисциплини. Изключително важно, решаващо значение в подкрепа на този процес има включването на катедрата в Проект No 3604 на програма TEMPUS на Европейския съюз „Дисциплини по обществено здравеопазване: подпомагане на университетското образование и квалификация на специалистите“, който дава възможност на целия преподавателски състав да повиши своята квалификация чрез включване в многобройни обучения в страната и чужбина. По този проект на обучение във Великобритания и Холандия за периоди от 1 до 6 месеца са били доц. д-р Станка Маркова (Кеймбридж, Единбург, Ротердам), гл. ас. д-р Юлияна Маринова (Ротердам), гл. ас. др Светлана Димитрова (Ротердам), гл. ас. Катя Пеева (Кеймбридж), ас. д-р Борислав Димитров (Ротердам). Тези обучения допринасят за развитието на университетското и следдипломното обучение по социална медицина с интегриране на иновативни елементи на съвременната епидемиология.

Учебната дисциплина „Медицинска етика“ се включва като задължителна в учебния план за студенти по медицина през 1993 г. Участието на проф. д-р Ст. Маркова, доц. д-р Ю. Маринова, доц. д-р Св. Димитрова и гл. ас. д-р Б. Парашкевова в международни курсове по биоетика (Холандия, Словакия, Румъния) изиграва важна роля за развитието на преподаването. Към настоящия момент, 25 години по-късно, проф. д-р Св. Димитрова, проф. д-р Ю. Маринова и доц. д-р Б. Парашкевова са членове на Международния форум на преподавателите (IFT) - UNESCO Chair in Bioethics, оглавяван от проф. д-р Сашка Попова.

Програмата по предмета „Въведение в компютьрната техника“, а по-късно „Медицинска информатика“ за студентите по медицина е разработена и във времето актуализирана в съответствие с новостите в тази област от гл. ас. Катя Пеева. По-късно тя разработва и съответните програми и учебни пособия по Информатика.

Като самостоятелна задължителна учебна дисциплина за студентите по медицина се утвърждава Биостатистиката. При разработването на учебната програма от преподавателите в катедрата са съобразени опита на изявени български и европейски институции и специалисти по биостатистика. Този опит е споделен в страната и чужбина, като решаващо значение има горепосочения проект по програма TEMPUS. Обучението по Социална медицина се развива, като учебната програма се адаптира съобразно най-новите научни постижения в областта на общественото здраве. Акцент се поставя на съвременната епидемиология и промоция на здравето.

Сътрудниците на катедрата имат съществен принос 
за въвеждането на обучението по Обща медицина в МФ, Стара Загора. Като член на екип преподаватели, подготвени във Великобритания, Полша и България и локален експерт по образование в рамките на съответния проект по програма PHARE (1996-1998 г.), гл. ас. д-р Св. Димитрова участва активно в изработването на учебните програми и в студентското обучение по обща медицина.

От 2004 г. в Медицинския факултет се провежда обучение на студенти по специалност „Управление на здравните грижи“. Основен принос за развитието на новата специалност имат сьтрудниците на катедрата с изключителната подкрепа на изтькнати специалисти в областта на социалната медицина от Факултет по обществено здраве, МУ - София под ръководството на проф. д-р Цекомир Воденичаров, дмн. От този момент и до сега тази подкрепа е значителна. Следва да подчертаем приноса на доц. д-р Кирил Кирилов, дм. за обучението по дисциплината „Основи на управлението в здравеопазването“с бакалаври и магистри; на доц. Мирчо Вуков, дм от НЦОЗ - София за развитието на преподаването по дисциплината „Медицинска информатика и биостатистика“. Ценно е сътрудничеството и подкрепата на доц. д-р Невяна Фесчиева, дм - ФОЗ, МУ - Варна като преподавател по „Епидемиология на здравето“ и като научен ръководител на докторанти в катедрата. Проф. Димитър Костов, дсн има принос за развитието на преподаването по дисциплината „Икономика на здравеопазването“. Проф. д-р Асен Петков, дм и проф. д-р Станка Маркова, дм оказват съществена подкрепа за преподаването по Управление на здравните грижи.

Към настоящия момент в катедрата се провежда обучение на студенти от всички специалности в направленията Медицина, Здравни грижи и Обществено здраве в Медицинския факултет, Тракийски университет - Стара Загора.

Сътрудниците на катедрата участват в следдипломното обучение на специализанти по Социална медицина и Обща медицина и активно се включват в различните форми на продължаващо обучение, осъществявани в Медицински факултет.

Успоредно с учебно-преподавателската, от самото основаване на катедрата се развива и научно-изследователската дейност. Областите на научен интерес на академичния състав са широкообхватни и насочени към актуални проблеми на общественото здраве с приноси, имащи важни приложни аспекти. Основните области на научноизследователска дейност бихме обобщили като:

- здравно състояние на населението: исторически поглед; индикатори; състояние и тенденции;

- предизвикателства пред съвременната медицинска етика: етични аспекти на сексуалното и репродуктивно здраве и права̀; етика на аборта; медико-етични проблеми, свързани със взаимоотношенията лекар-пациент; информирано съгласие на пациента; права̀ на пациента;

- медицинско образование: иновации; оценка качество на обучението;

- здравнополитически проблеми в условията на здравна реформа: актуални проблеми на общата медицинска практика; управление на човешките ресурси; майчино и детско здравеопазване;

- съвременна епидемиология;

- медицинска информатика и биостатистика;

- история на медицината.

Академичният състав на катедрата активно е участвал и продължава да работи по повече от 20 международни, национални и университетски научни проекти.

Кьм настоящия момент в катедрата се провежда последователен и непрекъснат процес на подготовка на докторанти по научните специалности „Социална медицина и организация на здравеопазването и фармацията“ и „Управление на здравните грижи“.

35-годишен период на развитие е основание за размисъл и равносметка на изминатия път, предизвикателствата и перспективите за бъдещето, както и повод да изразим признателността, благодарността, уважението и почитта към делото на нашите ръководители и учители, на които дължим това, което сме постигнали. Не бихме имали сегашния си облик, без подкрепата и сътрудничеството на колегиалната общност от университета и в страната, за което изразяваме дълбока благодарност. На тази подкрепа и сътрудничество разчитаме и занапред.

$$
* *
$$

\section{Проф. Здравко Богданов на 90 години}

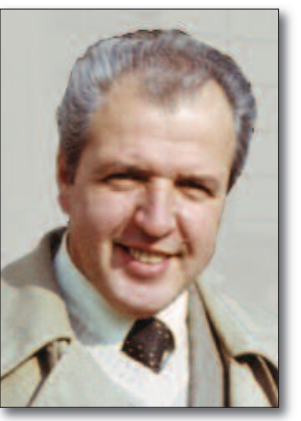

Редколегията на сп. “Социална медицина” честити юбилея на проф. Здравко Богданов по случай неговата 90-годишнина. Неговият дългогодишен професионален път е целенасочено отдаден на здравнодемографската статистика в нейния пълен цикъл - от изграждането на системата на събране на данни до систематизирането и анализирането на здравно-статистическата информация. В тази област той остави достойни дела като успешен учен, ръоводител и преподавател. В резултат на неговата упорита научнопроучвателна и приложна дейност са останали ценни анализи за здравното-демографското състояние на населението, които са използвани за вземането на решения от специалистите на Министерстото на здравеопазването и НОИ.

Защитава дисертация на тема „Основни причини за умиранията в България“. Избран е за ст.н.с. в НИСХОЗ под ръководството на проф. Тодор Захариев, където участва в осъществяването на най-голямото изследване до сега за здравното състояние на населението. Продължава работата си в ГИИЦ при МЗ. Самостоятелно извършва мащабно проучване за социално-медицинските аспекти на инвалидността в страната (1980-1986) и става доктор на медицинските науки. Работи като съветник в МЗ при министрите проф. Ив. Черноземски и доц. Н. Василев. Консултант е на Европейското бюро на СЗО в облаастта на здравно-демографската статистика. Преподавател е във Великотърновския универсиситет.

Проф. Здравко Богданов винаги е работел всеотдайно, с разбиране, толерантност, и усмивка към хората около него. Затова и днес остава обичан и уважаван от колегите, които се превърнаха в приятели. Бъди здрав и в добро настроение проф. Богданов! 